\title{
Credit Risk and Disclosure Behavior in the Bank Industry: Evidence From Saudi Arabia
}

\author{
Hind Qadiri \\ Ms of Accounting, College of Economics and Administrative Sciences \\ Imam Mohammad Bin Saud Islamic University, Riyadh, Saudi Arabia
}

Sulaiman Alsughayer (Corresponding author)

College of Economics and Administrative Sciences

Imam Mohammad Bin Saud Islamic University, Riyadh, Saudi Arabia

E-mail: sasojur@imamu.com.sa

Received: June 24, 2021

Accepted: July 10, 2021

Published: July 19, 2021

doi: 10.5296/ijafr.v11i3.18797

URL: https://doi.org/10.5296/ijafr.v11i3.18797

\begin{abstract}
This study investigates the extent of credit risk disclosure and the effects of bank-specific attributes on the disclosure level of Saudi listed banks. The study considers the content analysis of 12 Saudi listed banks from 2016 to 2020. A comprehensive credit risk disclosure index is developed, covering seven dimensions to measure the levels of credit risk disclosure. The generalized linear model is used to examine whether bank-specific attributes could explain any differences in disclosure levels among banks. This research provides evidence that although banks have similar regulatory requirements, they differ in their credit risk disclosure. The empirical results indicate that few bank-specific attributes significantly influence the risk disclosure. Bank size and leverage positively affect risk disclosure. Therefore, banks' asset size is a key factor in all risk disclosure categories. In contrast, the results show that a bank's age and profitability have no impact on the level of credit risk disclosure. This paper contributes to the risk disclosure literature in Saudi Arabia. Understanding factors that affect the level of credit risk disclosure might help the regulators to formulate strategies and policies, enabling shareholders and investors to make informed decisions.
\end{abstract}

Keywords: credit risk, agency theory, credit risk disclosure, disclosure index 


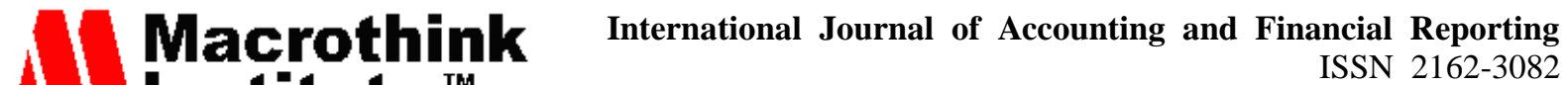 2021, Vol. 11, No. 3}

\section{Introduction}

No doubt, the management of bank risk is vital to the potent operation of the financial system (Berger et al., 2017). A robust internal bank control system assists in protecting a bank against expected losses from several risks (Dionne, 2013). Bank control system importance was proven explicitly by the subprime mortgage crisis of 2007 when many banks went bankrupt (Adams \& Ferreira, 2009). Undoubtedly, credit risks are considered the most dominant risk in the banking environment since credit operations inside banks are the most attractive investment to achieve profits (Abed et al., 2016). Numerous researchers have recently concluded that risk data drawn from the banks' financial statements effectively resolves data shortages. Yet, most of the financial statement's content has the drawback of 'hysteresis' (Beneish et al., 2015). Moreover, this financial statement information can describe historical profiles of bank risk and neglect future bank risk conditions.

The use of historical data disregards changes in risk aggregation and leads to the generation of expected future losses beyond adequate capital. Further, investors need forward-looking disclosures more than past operation disclosures. Given the importance of forward-looking information from an investor's perception, banks' regulatory guidelines emphasized the disclosure of any uncertainties and unforeseen plans that are expected to significantly influence the future processes of banks (Muslu et al., 2015). Narrative risk disclosures are forward-looking sources of bank risk information that contribute a detailed bank risk losses description (Zhu et al., 2016).

Although the growing relevance of risk disclosure enhances the efficiency of financial markets and promotes financial stability, the scope of this research area has been largely ignored. Recently, credit risk management and modeling have received renewed attention from developing countries and economies. It is noteworthy that while most of the literature reflects many research on disclosures, there is limited research on corporate risk disclosures, especially with respect to financial institutions (Beasley et al., 2005). Further, previous risk disclosure researches have mainly focused on either non-financial companies or voluntary risk information. Mandatory risk disclosure provided by banks still needs more research (Oliveira et al., 2011a). This research scarcity is even more vital in the context of developing countries, including Saudi Arabia. Most risk disclosure studies are limited to developed countries, for instance (Abraham \& Cox, 2007; Deumes \& Knechel, 2008; Dobler et al., 2011; Solomon et al., 2000; Beretta \& Bozzolan, 2004; Combes-ThuÚlin et al., 2006; Oliveira et al., 2011a; Barakat \& Hussainey, 2013). The lack of research on financial institutions' disclosures, especially credit risk, is the primary motivation of this research.

The main objective of this study is to investigate the extent of credit risk disclosure and study the effect of bank-specific attributes on the level of disclosure from 2016 to 2020. In order to achieve the research objectives, four hypotheses were developed to examine the impact of bank-specific characteristics on the quality of disclosure, including bank size, bank age, profitability, and leverage.

Credit risk disclosure has great importance for several reasons. First, the increase of credit risk disclosure in general, especially in the banking industry, is due to the application of the 
Basel conventions. This study focuses on financial institutions because banks are risk-oriented institutions and their core business is to provide liquidity and take risks (Bessis, 2011). In addition, banks are subjected to a stringent market discipline. Therefore, the enhancement of bank credit risk disclosure contributes more to the overall financial market stability, transparency, and strength. However, the review of the risk disclosure literature shows that the banking industry is still under-researched.

Second, there is less information about bank risk in Saudi Arabia. For the researcher, no study has provided empirical evidence to the extent of risk credit disclosure and the factors affecting Saudi listed banks' decision to disclose risk information. To fill this gap, this paper considers the non-automated approach to content analysis of annual reports. Saudi banks have been exposed and are expected to be exposed to various credit risks due to the large number of financing loans accompanied by the housing program as a part of Saudi 2030 vision objectives. In cooperation with banks, the Real Estate Development Fund announced more than 300,000 real estate loans in 2017 until the end of July 2020, which entails more risk exposure (Sakani, 2020). Last, few empirical studies use the index approach to investigate risk disclosure levels in the annual reports of Saudi listed banks. The research findings should be helpful to practitioners, academics, and policymakers of Saudi Arabia and other countries having similar conditions.

\section{Conceptual Framework}

\subsection{Credit Risk}

The financial industry is facing various risks worldwide. Significant institutional changes have taken place in the regulation, management, and measurement of risk. Credit risk, the most significant risk in the banking sector, is no longer a mere figure in the balance sheet reported until paid or written off but nowadays packaged and traded. Today, regulators, ranking agencies, companies, and investors are linked in the credit chain. Every day, new analytic tools to control, manage, and measure are created and promoted. Credit risk is essential for banks and investors as they might not receive their agreed payments if a firm does default (Linsley \& Shrives, 2006). There are several definitions of the credit risk concept, but it is defined as an expected loss if a bank borrowing client or third party failed to meet obligations as agreed (Bank of International Settlements, 2010). It refers to the probability that a borrower will default to repay loans and debts due to the firm-specific events and attributes (Brown \& Moles, 2014).

For their sake to maximize profits, banks are attracted mostly by credit operations that are considered the riskiest investments due to the various risks that could lead to the collapse of many banks. Nowadays, credit risk's concept has overlapped with managing banks' activities. As a result, it is becoming more in line with the risk management concept. Banks seek to deal with and manage their credit risk rather than avoiding it (Faybishenko et al., 2008). According to Asllanaj (2018), banks might suffer from credit risk for four main reasons: inadequate management practices leading to bad debts; inefficient and ineffective mechanisms to reduce bad debt; illegal insider trading; poor credit management, where techniques or decisions to decrease bad debt are inadequate. Although healthy banking 


\section{Mll Macrothink}

International Journal of Accounting and Financial Reporting ISSN 2162-3082 2021, Vol. 11, No. 3

systems significantly impact economic development, weakly regulated systems may adversely affect the entire economy, leading to a financial crisis (Scannella \& Polizzi, 2020). According to the Bank for International Committee (1999), credit risk disclosure regulation is a source of instability in the banking sector. The recent global financial crisis has demonstrated how poor credit risk management and regulations have directly affected many economies (Linsley \& Kajuter, 2008).

Information about credit risk is essential for the proper mechanism of the market and financial system (Nier \& Baumann, 2006). The availability of credit risk information in banks' annual reports contributes to financial stability. The risk disclosure and reporting practices of listed banks rely on the legal, economic, cultural, and financial markets. Dobler (2005) defines risk reporting as a probabilistic forecast disclosure. Jorgensen and Kirschenheiter (2003) explain risk disclosure as disclosing the corporate-specific variance of future cash flows.

\subsection{Risk Disclosure}

Adequate risk disclosure is vital in enhancing market discipline and gaining stakeholders' trust. Linsley \& Shrives (2006, p.389) define risk disclosure from a broad perspective as "information related to opportunities, prospect, hazard, harm, threat, or exposure that has already impacted or may impact on a company in the future." Hassan (2009, p.669) distinguishes risk disclosure included in the financial statements as the "information about managers' estimates, judgments, reliance on market-based accounting policies, such as impairment, derivative hedging, financial instruments, and fair value as well as the disclosure of concentrated operations, non-financial information about corporations' plans, recruiting strategy and other operational, economic, political and financial risks." From the stakeholders' perspective, the information about risks and management is critical in making informed decisions (Lajili, 2009).

Due to the significance of risk disclosure, banks tend to disclose financial and non-financial information for providing performance details to stakeholders, which eventually improves the company's reputation and ultimately ensures competitive advantage and sustainability of profitability (Hassan, 2009; Romero et al., 2014). Information about credit risk could be an effective tool to reduce investors' uncertainties and influence the public view about banks' risk profile. Disclosure in annual reports is categorized as mandatory demanded by regulatory bodies and authorities or voluntary beyond the mandatory requirements (Diamond \& Verrecchia, 1991; Gernon \& Meek, 2001). In the absence of particular mandatory risk disclosure regulations or guidelines, as is the case in most emergent countries, banks may tend to disclose credit information voluntarily in an attempt to enhance the investors' confidence (Shrives \& Linsley, 2003).

The importance of credit risk reporting is guided by the International Accounting Standards Board (IASB) and Basel committee (Cabedo \& Tirado, 2004). IASB introduced general standards (e.g., International Accounting Standards (IAS), which are adopted worldwide. IAS 32 presents financial instruments to provide disclosures of risk and uncertain information, and IAS 37 outlines provisions, contingent assets, and liabilities related to credit risk. In 
addition, IASB established IFRS 7 to improve financial disclosures arising from the financial instruments (IASB, 2007). Furthermore, IFRS 9 has been released by 2018, requiring banks to recognize the decline in value sooner and estimate expected future losses against a wider series of assets (Blažeková, 2017).

In addition, recommendations on banking laws and regulations are issued by the Basel Committee in 2006. Basel II became a directive in different countries to organize and measure financial and operational risks at individual banking institutions, hence providing risk management and supervision requirements. More specifically, market discipline in Pillar 3 outlines disclosure requirements of risk information, profile, assessment process, and capital adequacy, which enhance the bank disclosures and market discipline (Nahar et al., 2016).

\subsection{Risk Disclosures in Saudi Arabia}

Saudi Arabia, being the world's largest producer of crude oil, is one of the speedily emerging economies in Asia and the Middle East (Falgi, 2009; Piesse et al., 2012). Previously, Saudi's economy primarily relies on crude oil exports as the main source of government revenue. Recently, the dependence on oil revenue has decreased dramatically due to Saudi Vision 2030, which aims to reduce Saudi Arabia's dependence on oil. It is noteworthy that Saudi Arabia has the largest stock market of all Arab countries. In recent years, the growth of the Saudi capital market was very high, with a massive increase in value and transactions. Although the Saudi stock market is enormous compared to other Arab markets, studies have asserted that it is inefficient like most of the other markets (Dahel, 1999; Onour, 2004).

Saudi Arabia has experienced various reforms and improvements, enabling it to become a member of the World Trade Organisation (WTO) in 2005. Moreover, the Saudi stock market was later opened to foreign investors for enlarging the activities and transactions. In general, Saudi's business environment has witnessed several improvements contributing to its healthy economy.

Currently, five central authorities regulate and supervise businesses in Saudi Arabia. The central bank (SAMA), the Ministry of Commerce (MC), the Saudi Organization for Chartered Public Accountants (SOCPA), the Capital Market Authority (CMA), the Saudi Stock Exchanges (Tadawul), and the Central Bank (SAMA) are responsible for overseeing the financial sectors authorized to operate in Saudi Arabia including banks, insurance companies, finance companies, exchange institutions, and credit information companies (SAMA, 2021). SAMA, established in 1925, is responsible to control the banking sector and its soundness and effectiveness in performing functions for the service of Saudi Arabia in general and users of its services and stakeholders. The most important functions of SAMA include regulating, supervising, and promoting the soundness of the financial sector; enhance the risk culture while also raise the level of compliance with the international, local, and internal regulations; issue and manage banknotes; formulate and implement monetary and financial policies (SAMA, 2021).

The MC plays a supervisory role over other monitoring bodies, such as SOCPA, CMA, and 


\section{Macrothink}

International Journal of Accounting and Financial Reporting ISSN 2162-3082 2021, Vol. 11, No. 3

Tadawul. SOCPA, a professional accounting body started in 1991 by the MC, is responsible for establishing and operating quality assurance review systems under the supervision of the MC. It is also accountable for setting accounting and auditing standards. CMA has the role of regulating Saudi listed companies by issuing rules and regulations that enhance transparency and protect investors (CMA, 2007). Transparency and disclosure regulations are among the most critical announcements issued by the CMA. Tadawul, an Arabic term, refers to a self-regulated authority governed by nine board members representing different governmental authorities nominated by CMA (Saudi Exchange, 2009).

Many reforms in the banking industry have occurred since 2004. First, SAMA followed Basel II guidelines and used the Pillar 2 requirements to enhance banks' risk management and capital planning. Later on, it introduced Basel III requirements (IMF, 2013) and launched international financial and reporting standards (IFRS) for banks and their auditors with notable success.

\subsection{Literature Review}

Risk disclosure literature is similar to that in the general disclosure literature. Studies examine risk disclosure in terms of quantity (Linsley \& Shrives, 2006) and quality (Beretta \& Bozzolan, 2004), and firm-specific attributes (Rajab \& Schachler, 2009) or corporate governance mechanisms (Abraham \& Cox, 2007; Taylor, 2011). To date, most risk disclosure research has been conducted in developed countries, for instance (Solomon et al., 2000; Beretta \& Bozzolan, 2004; Combes-ThuÚlin et al., 2006; Abraham \& Cox, 2007; Deumes \& Knechel, 2008; Dobler et al., 2011; Oliveira et al., 2011a; Barakat \& Hussainey, 2013). Most of these studies investigate the attributes that drive risk disclosure in specific industries, which are considered essential to management, investors, and regulatory authorities.

A review of the related literature shows that most researchers consider annual reports as a source of content analysis for risk disclosure. Prior studies have examined the importance of risk disclosure; however, the disclosure deficiencies in annual reports persisted to all firms globally. Recent studies confirm that transparency issues still exist even after adopting IFRS 7 and Basel II (Oliveira et al., 2011a). Woods et al. (2008) reviewed the annual reports of 190 Portuguese credit institutions and found a lower level of disclosure. They concluded that disclosures have transparency flaws and insufficient and incomparable from the perception of the users. They argued that the misalignment of disclosure and related narratives led to issues of understandability, relevance, and reliability (Oliveira et al., 2011b). Boussanni et al. (2008) surveyed European banks and highlighted the deficiencies in the liquidity risk disclosures level and extent of these banks especially related to planning and internal controls disclosures.

In the context of Saudi Arabia, many researchers have indicated that the current risk reports do not convey the actual reality in the financial statements and annual reports (Sidawi, 2014; Al-Maghzom et al., 2016; Ibrahim et al., 2019). Furthermore, these studies emphasize the poor transparency features and non-compliance with minimum mandatory requirements. Therefore, further investigation is needed not only for risk disclosure but also for all types of disclosure. 


\section{Mll Macrothink}

International Journal of Accounting and Financial Reporting

ISSN 2162-3082

2021, Vol. 11, No. 3

A review of the literature indicates that financial statement approaches are critical to bank risk aggregation. However, prior studies only focused on and used numerical values. Although it is essential to measure credit risk level through quantitative information, such as financial ratios, loan loss reserve, and provision as proxies for credit risk, some problems could be posed for banks due to using accounting information alone at the institutional level. Accounting figures and ratios might not be informative in forecasting and estimating potential outcomes. Actual asset values differ from the historical value due to the conservative recording methods (Altman \& Saunders, 1997), and accounting values could be manipulated (Agarwal \& O'Hara, 2007; Bharath \& Shumway, 2008). Beretta and Bozzolan (2008) criticize the common notion of disclosure quantity provided in the financial statements as it cannot be a proxy for information quality.

Hence, the literature investigating risk disclosure quality based on forward-looking information may be dramatically valuable, particularly on risk disclosure in annual reports using content analysis (Scannella \& Polizzi, 2020). In this regard, a significant stream of literature is performed employing content analysis to evaluate reporting of risk (Barth \& Landsman, 2010; Scannella, 2018; Scannella \& Polizzi, 2018). Scholars have designed disclosure indexes to review and evaluate risk disclosure in annual reports (Gray et al., 1984; Tonkin, 1989). Some tried to assess whether there are associations among certain independent variables (Cooke, 1989), such as firm size and financial leverage (Chow \& Wong-Boren, 1987). These studies assert that content analysis is a valuable and robust methodology to investigate risk disclosure.

However, the literature is limited to developed countries and focuses only on quantitative risk reporting methods for financial statements (Scannella \& Polizzi, 2020). Therefore, a proper investigation on this topic is needed to cover both backward-looking and forward-looking disclosures. In this regard, this research incorporates forward-looking textual and numerical risk disclosures to overcome the drawbacks of risk aggregation, resulting from using historical numerical data only. In turn, the study obtains more reasonable aggregate risk results. So, this research addresses this problem by considering qualitative and quantitative credit risk information in annual reports.

\subsection{Hypothesis Development}

Previous literature on disclosure has focused on many theories, e.g., stakeholder theory (Amran \& Devi, 2008), Institutional theory (M. K. Hassan, 2009), agency theory (Abraham \& Cox, 2007; Lookman, 2009), legitimacy theory (Oliveira et al., 2011b), and signaling theory (Linsley \& Shrives, 2000). However, no single theory can completely articulate disclosure (Linsley \& Shrives, 2000). This study dictates the use of agency theory and signaling theory to explore the credit risk disclosure quality in the banking sector. Several empirical studies use some unique characteristics of these theories to explain how they might be applied to the banking industry and provide evidence that various entity attributes affect the corporate disclosure levels, although the empirical findings are inconclusive, as explained below. 


\section{Macrothink \\ International Journal of Accounting and Financial Reporting \\ ISSN 2162-3082 \\ 2021, Vol. 11, No. 3}

\subsubsection{Bank Size}

Firm size is the most widely used and highly linked with disclosure, including almost in every disclosure study as the variable and strong driver for disclosure (Ahn \& Lee, 2004). Many theoretical studies have explained the relationship between bank size and credit risk disclosure. For example, agency theory claims that the information asymmetry between shareholders (the agent) and managers (the principal) can be controlled and reduced by implementing monitoring mechanisms that will probably provide higher disclosure levels of information (Jensen \& Meckling, 1976). As, investors have no active role to play in institutions, the management tends to maximize their interests and values. Therefore, risk information would reduce the investors' uncertainties. To fit with the agency theory, studies noted that larger banks tend to distinguish themselves by sharing more risk information to reduce information asymmetry and monitoring costs (Abraham \& Cox, 2007).

Numerous empirical researches on risk disclosure examined the association of company size and level and extent of risk disclosure and found a significant correlation between size and disclosure, e.g., (Mohobbot \& Konishi, 2005; Linsley \& Shrives, 2006; Abraham \& Cox, 2007). Abraham and Cox (2007) examined the relationship of US firms' characteristics to the amount of risk disclosure. Firm size was found to affect the risk disclosure level positively. However, other studies found no association, e.g., (Beretta \& Bozzolan, 2004; A. Hassan, 2009; Rajab \& Schachler, 2009). Beretta and Bozzolan (2004) reported a non-significant relationship between company size and the extent of risk disclosure. This study examines the correlation between bank size and credit risk disclosure using the following hypothesis:

(H1): There is a positive association between credit risk disclosure and bank size.

\subsubsection{Bank Age}

Recent literature assumes that old firms could enhance their information disclosure over time (Alsaeed, 2006; Alfraih \& Almutawa, 2014; Demir \& Bahadir, 2014). In contrast, new small and medium enterprises may focus on developing their products and market share rather than focusing on disclosure as they are more likely to have less accounting information quality and business experience (Glaum \& Street, 2003). Old banks may already have experienced managers and well-established procedures to deal with the technical aspects of financial reporting. The older the banks in operations, the higher their public image and reputation are likely to be. Undoubtedly, higher disclosure levels are expected to develop and foster more reputation (Hamid, 2004; Oliveira et al., 2011a; Sánchez-Ballesta \& Lloréns, 2010). While many studies have shown a positive relationship between bank age and corporate narrative risk disclosures (El-Bannany, 2015), few studies found an insignificant association between the two variables (Grassa et al., 2019). This study examines the connection between bank age and risk disclosure using the second hypotheses:

(H2): There is a positive association between credit risk disclosure and bank age.

\subsubsection{Profitability}

Being an informative success indicator, profitability is a critical determinant for the users of 


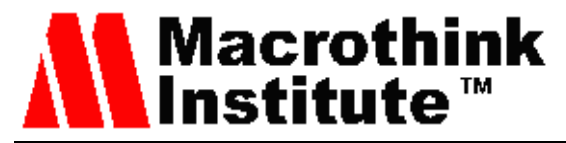

International Journal of Accounting and Financial Reporting

ISSN 2162-3082

2021, Vol. 11, No. 3

annual reports that reflects the effectiveness and efficiency of management and internal systems. The management of more profitable firms is keen to provide more narrative disclosure (El-Bannany, 2015). Signaling theory indicates that profitable firms report more to inform stakeholders about their excellent performance. Moreover, managers will be keen to signal their unique risk management abilities to the market by disclosing risk information in the annual report (Konishi \& Ali, 2007).

Empirical studies have explored the association between profitability and risk disclosure, and the results have been inconclusive. For example, although Al-Maghzom et al. (2016) found a positive correlation between profitability and disclosure, (Konishi \& Ali, 2007) found no significant association between the two variables. This study examines the connection between bank profitability and risk disclosure using the third hypotheses:

(H3): There is a positive association between credit risk disclosure and profitability.

\subsubsection{Leverage}

Recent risk disclosure literature suggests that firms characterized by a high leverage ratio tend to be at greater risk (Amran et al., 2009; Elshandidy et al., 2013). Therefore, highly leveraged firms may have more incentive to disclose their risk and send good signals of their debts (Naser et al., 2002). From a signaling theory perspective, companies, having higher risk leverage, will be keen to disclose risk information to signal investors and stakeholders that they have an efficient risk management system and management competence in handling such risk (Linsley \& Shrives, 2006). In addition, agency theory indicates that higher leverage levels firms satisfy creditors by disclosing more information voluntarily to remove any suspicions of wealth monopoly (Popova et al., 2013). Consequently, good information disclosure about banks' credit risk might play an essential role in mitigating the concerns of creditors regarding the bank's solvency and capability to generate enough cash flows over time.

Empirical results on the relationship between risk disclosure and leverage ratio were also inconclusive. While some studies' findings show a positive relationship between them (Deumes, 2008; Elshandidy et al., 2013), other studies have demonstrated insignificant associations between the two variables (Miihkinen, 2012; Ntim et al., 2013). Thus, it can be concluded that the determinants of risk disclosure in the annual reports of listed banks have yet to be fully explored. This study examines the connection between bank leverage and risk disclosure using the fourth hypotheses:

(H4): There is a positive association between credit risk disclosure and leverage.

\section{Research Methodology}

\subsection{Variables of the Study}

This study uses two categories of variables: dependent and independent variables. Table 1 summarises the variable definition, measurement, and source of the data. 


\subsubsection{Dependent Variables}

The selected dependent variable for this study is credit risk disclosure. The unweighted approach is being used for a risk disclosure index to score the credit disclosure for banks. This approach is popular in literature and used by several studies (Akhtaruddin et al., 2009; Alsaeed, 2006; Ghazali \& Weetman, 2006; Kristandl \& Bontis, 2007; Patelli \& Prencipe, 2007).

\subsubsection{Independent Variables}

Several empirical studies prove that various firm attributes affect the risk disclosure levels; hence, four independent variables were selected representing a group of bank characteristics, including bank size, bank age, profitability, and leverage.

Table 1. Definition and measurement of variables

\begin{tabular}{|c|c|c|c|c|}
\hline Category & Variable & Definition & Measurement & Data source \\
\hline Dependent Variable & CRD & $\begin{array}{l}\text { Credit risk } \\
\text { disclosure } \\
\text { index }\end{array}$ & $\begin{array}{l}\text { The total number of } \\
\text { points awarded for } \\
\text { credit risk disclosure, } \\
\text { each item scored } 1 \text { if } \\
\text { disclosed and } 0 \text { if not. }\end{array}$ & Annual reports \\
\hline \multirow{4}{*}{$\begin{array}{l}\text { Independent Variables } \\
\text { (Firm-specific } \\
\text { Attributes) }\end{array}$} & BS & Bank size & $\begin{array}{l}\text { Natural logarithm of total } \\
\text { assets }\end{array}$ & Bank websites \\
\hline & $B A$ & Bank age & Number of years & Bank website \\
\hline & LEV & Leverage & $\begin{array}{l}\text { Long-term debt/ total } \\
\text { assets }\end{array}$ & $\begin{array}{l}\text { Annual reports: } \\
\text { Financial statements }\end{array}$ \\
\hline & PRO & Profitability & $\begin{array}{l}\text { Measurements by return } \\
\text { on equity }\end{array}$ & Bloomberg \\
\hline
\end{tabular}

Source: developed by the researcher

\subsection{Data Collection}

The research uses a traditional content analysis approach in disclosure studies to assess the level of credit risk disclosure across Saudi listed banks. Krippendorff (2018) asserts that content analysis guarantees repeatability and valid inferences from data based on their contexts. This study collects data from annual reports, which cover different aspects of banks' financial and non-financial performances. This research analyses the credit risk-related information by all narrative sections in several annual reports, including financial statements, the annual board of directors' reports, and bank websites.

This research developed a credit risk disclosure index to measure the level of risk disclosure in Saudi listed banks. This approach is similar to the technique used by prior risk disclosure 
studies (Frolov, 2006; Linsley \&Shrives, 2006; Linsley \& Shrives, 2000; Nahar et al., 2016; Oliveira et al., 2011a). Scholars adopted different coding schemes when conducting content analysis, including sentences, keywords, or pages as a measurement unit. This method was adopted and congruent with recent risk disclosure studies (Abdallah et al., 2015; Elshandidy et al., 2015; Grassa et al., 2019, 2020; Nahar et al., 2016; Scannella \& Polizzi, 2021).

This study adopted two steps process. First, it reviews past studies related to risk disclosure and identifies common items used to assess the banks' risk disclosure. Second, it derives the index categories and items from multiple sources of regulatory information requirements (IFRS 7; IFRS 9, Basel II; and IFSB). As a result, the risk disclosure index included 30 items grouped into seven specific credit risk information categories (Appendix A).

The study defines credit risk disclosures by any sentence about any "opportunity or prospect, danger, harm, hazard, threat, or exposure that has already impacted or may impact" the bank's operations (Linsley and Shrive, 2006, p. 389). The content of each bank's annual reports is compared with the listed items. The basis of a dichotomous model is coded as one if an item is disclosed or zero if otherwise. Annual reports for the sample are downloaded from the banks' websites and Tadawul. The examination of data allows the researcher to identify any changes in credit risk disclosure levels that may have occurred over the period covered in the study.

\subsection{Sample}

This research reviewed credit risk disclosure in annual reports of 12 Saudi listed banks on Tadawul from 2016 to 2020 . A total of 6,597 pages were covered and analyzed in disclosure reports. This country-specific sample enables comparisons for a year or overtime of the same bank and among banks, as banks are subjected to similar regulatory and reporting requirements. The time horizon of this research runs from 2016 to 2020. Accordingly, this study covers a five-year period that paves the way for a more comprehensive credit risk disclosure analysis. This period enables the study to collect a large amount of information, even from a pretty small sample, combining qualitative and quantitative data. This period is chosen mainly due to a large number of financing loans as targeted by the housing program, one of the main initiatives of the Saudi Vision 2030. In addition, this time horizon fits to analyze the recent impacts of Pillar 3 and IFRS 9 in the banking industry of Saudi Arabia.

\subsection{Statistical Analysis Technique}

Traditionally, linear regression has been the commonly used technique to predict banking risk. This paper uses the generalized linear model (GLIM or GLM) presented by Nelder and Wedderburn (1972) to make traditional regression model assumptions more realistic for fitting into practical reality. Recently, this model has been used in a wide field of research (Calabrese \& Osmetti, 2013; Ogunwole, 2019; Pepe, 2000). GLM is a regression model. A dependent variable follows one of the probability distributions that belong to the exponential family, and these models are considered less restrictive than traditional regression models. According to Papke and Wooldridge (1996), the GLM is considered an effective way to estimate the fractional response in the risk disclosures score and mitigate concerns regarding 


\section{Al Macrothink \\ International Journal of Accounting and Financial Reporting \\ ISSN 2162-3082 \\ 2021, Vol. 11, No. 3}

the regress and being bounded index level between 0 and 1 .

The GLM differs from the linear regression model that the expected value of the response variable is replaced by the link function $(g(\mu)=\eta)$, whereas $\eta$ is a linear combination of independent variables, the primary purpose of using the link function is to make the error variance more stable.

To test the hypotheses of the study, the following model is used:

$$
C R D_{i t}=\alpha_{0}+\beta_{1} \mathrm{BS}+\beta_{2} \mathrm{BA}+\beta_{3} \mathrm{PRO}+\beta_{4} \mathrm{LEV}+\varepsilon_{\mathrm{it}}
$$

\section{Results and Empirical Analysis}

\subsection{Descriptive Statistics}

The descriptive statistics, namely, minimum and maximum values, mean, standard deviation, and skewness of all variables, are presented in Table 4.1. This study uses a checklist of 30 items to measure the credit risk disclosure of the banking sector. The maximum proportionate value of credit risk disclosure in the entire sample is $91 \%$. Such results indicate that the banks' disclosure score goes to $91 \%$ and disclose most of the checklist items in their annual reports. At the same time, the minimum score value is $32.35 \%$ referring that some banks disclose only $32.35 \%$ of disclosure checklist items in annual reports.

Furthermore, the mean is $76.1 \%$. This result shows that, on average, the sample discloses $76.1 \%$ of the checklist elements, which is considered a high percentage compared to the maximum value of disclosure by the banks, i.e., 91.18\%. Further, it shows that, in credit exposures, both credit exposure size and expected loss rate are well reported by Saudi banking. Also, Table 2 gives the standard deviation for each variable, where all standard deviations are less than or equal to 15 . Finally, all the skewness values are between -3 and +3 . This presents that the data is symmetric.

Table 2. Descriptive statistics of variables

\begin{tabular}{cccccccc}
\hline Variables & $\mathbf{N}$ & Minimum & Maximum & Mean & Std. & \multicolumn{2}{c}{ Skewness } \\
\cline { 2 - 7 } & Statistic & Statistic & Statistic & Statistic & Statistic & Statistic & Std. Error \\
\hline CRD Index & 60 & 32.35 & 91.18 & 76.1065 & 13.61328 & $-1.539-$ & .309 \\
\hline BS & 60 & 15.00 & 21.56 & 18.7010 & 1.30076 & $-1.636-$ & .309 \\
\hline BA & 60 & 9.00 & 63.00 & 33.4167 & 15.06178 & $-.200-$ & .309 \\
\hline PRO & 60 & .29 & 20.42 & 10.5820 & 4.41781 & .072 & .311 \\
\hline
\end{tabular}




\subsection{Test the Significance of the Model}

The results, based on testing the significance of the model using the Omnibus test, are presented in Table 3. It is determined that the regression model used in the study is significant since the significance level shown in the test is less than 0.01 , which indicates that the model is suitably well specified.

Table 3. Omnibus Test

\begin{tabular}{ccc}
\hline \multicolumn{3}{c}{ Omnibus Test } \\
\hline Likelihood Ratio Chi-Square & Df & Sig. \\
\hline 45.512 & 4 & .000 \\
\hline
\end{tabular}

Note: the level of significance is less than 0.01

\subsection{Regression Results}

Table 4 shows the empirical results of regression analysis of the covariates during 2016-2020. The results show that bank attributes aggregately influence the quality of credit risk disclosure. The coefficient of determination (R-square) is equal to $54.9 \%$; this represents the effect of bank attributes aggregately on (CRD). The remaining percentage of (45.1\%) relates to other variables not included in the chosen model or random error. These variables could be driven by other mandatory regulations, Basel, or IFRS. However, all these variables could noticeably improve the disclosure levels. In this regard, the extent of credit risk disclosure rose gradually after adopting IFRS 9 by 2018.

The results depicted in Table 4 indicate that both independent variables (bank size and leverage) are significant hence affect disclosure due to their significance level less than 0.05 ( $\mathrm{sig}>0.05)$, which is a statistically significant value indicating the degree of a statistically significant correlation between the independent variables and CRD. Furthermore, since the study uses the natural logarithm of total assets as a proxy for bank size, listed Saudi banks with more assets disclose more risk exposures. Hence, if the bank size increases by one unit, then the expected value of the dependent variable (CRD) will go up by 0.301 .

Table 4. Regression results

Parameter Estimates

\begin{tabular}{cccccccc}
\hline Parameter & B & $\begin{array}{c}\text { Std. } \\
\text { Error }\end{array}$ & $\operatorname{Exp(B)}$ & $\begin{array}{c}\text { Wald } \\
\text { Chi-Square }\end{array}$ & Df & Sig. & R-square \\
\cline { 1 - 6 } (Intercept) & .462 & .0453 & 1.587 & 103.765 & 1 & .000 \\
\hline BS & .263 & .1017 & 1.301 & 6.682 & 1 & .010 & \\
\hline BA & .034 & .0531 & 1.035 & .418 & 1 & .518 & \multirow{2}{*}{.549} \\
\hline PRO & -.075 & .0648 & .928 & 1.330 & 1 & .249 & \\
\hline Lev & .231 & .0733 & 1.260 & 9.949 & 1 & .002 & \\
\hline
\end{tabular}




\section{Mll Macrothink}

International Journal of Accounting and Financial Reporting

ISSN 2162-3082

2021, Vol. 11, No. 3

Furthermore, the leverage coefficient is significant and positively associated with the bank disclosure of all risk exposure categories (at 0.05 level). So, banks having high leverage, disclose more information about credit risk. If the leverage increases by one unit, then the expected value of the dependent variable (CRD) will go up by 0.26 .

This primary finding provides insight that large size and high leverage play an essential role in the level of CRD of the domestic banking sector in Saudi Arabia. However, the bank age and profitability are insignificant, because the significance level is greater than 0.05 $(\operatorname{sig}<0.05)$. In this way, the higher the bank's age and profitability, the expected value of the dependent variable (CRD) decreases by $0.035,0.072$ respectively.

Overall, these results confirmed that some bank attributes affect the extent of credit risk disclosure and such finding is consistent with other studies in the literature for example, (Aryani \& Hussainey, 2017; Maffei et al., 2014; Nahar et al., 2016; Shrives \& Linsley, 2003).

\subsection{Hypotheses Testing}

\subsubsection{Bank Size}

This study used the natural logarithm of total assets as a proxy for bank size. This scale was widely used in past studies to measure bank size (Al-Maghzom et al., 2016; Nahar et al., 2016). The study shows that total assets significantly affect CRD. Thus, banks, having a large number of assets, disclose more risk exposures. This result is in line with agency and signaling theories, along with those researchers who considered that firm size is positively associated with risk disclosure (Abraham \& Cox, 2007; Aryani \& Hussainey, 2017; El-Bannany, 2015). Based on the analysis above, the first hypothesis is accepted.

(H1): There is a positive association between credit risk disclosure and bank size.

\subsubsection{Bank Age}

The primary results provide insight that bank age measured by the number of years for the bank since inception until the years considered in the study is negatively related to the CRD level, which contradicts the expectation of the second hypothesis. This result is inconsistent with recent literature results (Alfraih \& Almutawa, 2014; Alsaeed, 2006; Demir \& Bahadir, 2014; El-Bannany, 2015). Based on this analysis, the second hypothesis is rejected.

(H2): There is a positive association between credit risk disclosure and bank age.

\subsubsection{Profitability}

Although, signaling theory confirms that profitable corporates deliver signals to show their good performance. The study results indicate that profitability measured by ROE had no association with CRD and is consistent with the study of Aryani and Hussainey (2017). While this result is inconsistent with the analysis of agency theory, which asserts that less profitable firms disclose more to explain the reasons for their poor financial performance (Inchausti, 1997). Since the result contradicts the hypothesis, the third hypothesis is rejected.

(H3): There is a positive association between credit risk disclosure and profitability. 


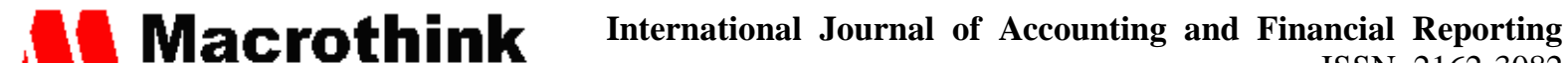 ISSN 2162-3082 2021, Vol. 11, No. 3}

\subsubsection{Leverage}

Considering the results of this study, highly leveraged listed banks disclose their performance more transparently and frequently. This result is consistent with Jensen and Meckling (1976), who argue that highly leveraged companies tend to give more narrative and meaningful information in their annual reports. It is also consistent with agency theory as highly leveraged firms satisfy their creditors by disclosing more information voluntarily (Popova et al., 2013). Therefore, based on the above analysis, the fourth hypothesis is accepted.

(H4): There is a positive association between credit risk disclosure and leverage.

\section{Conclusion and Discussion}

This research redresses the empirical scarcity of credit risk disclosure studies in developing countries by examining the effect of banks' attributes on the soundness of credit risk disclosure and providing insights into the risk disclosure practices of banks. It fills the literature gap by providing a comprehensive study of credit risk disclosure information in the Saudi banks' annual reports. Healthy banking systems exert a significant impact on economic growth and development. Banks are subjected to a stringent market discipline, and the enhancement of bank credit risk disclosure contributes to broader financial stability. A better knowledge of credit risk in the banking sector enhances the financial market transparency and strength.

The findings of the disclosure index appear that the percentages of credit risk disclosure range widely among banks even though they are subjected to homogeneous regulatory requirements and accounting standards; some differences still characterize their credit risk reporting. In the case of credit exposures, the findings show that both credit exposure size and expected loss are well reported by Saudi banking. Regulations provide enough flexibility in reporting bank performance with fair and adequate disclosure levels; hence, banks report an adequate amount of information.

Using a credit risk disclosure index, this research provides useful theoretical and policy implications and preliminary evidence of credit risk disclosure. The findings of the disclosure index illustrate that Saudi listed banks significantly improved their risk disclosure over time. Such improvement is associated with the disclosure of specific risks, consistent with agency and signaling theories. The trend of the extent of risk disclosure rose gradually significantly. This improvement is associated with the emergence of IFRS 9 and the mandatory application of Basell requirements. However, the coronavirus (Covid-19) spread affected the preparation and review of financial statements substantially. Although the IFRS 9 requires credit losses to be recognized by the institutions and allows them to amend their approach to determine expected credit losses under different circumstances. The study noticed a significant decrease in the level of disclosure in Saudi listed banks in 2020. So, banks should not continue to their previous lack of credit loss reporting beyond 2020. Banks must have strategic plans and be fully prepared for such exceptional circumstances to maintain a minimum level of mandatory disclosure requirements.

After a thorough identification of the main elements related to credit risk, this methodological 
tool can be applied to investigate risk disclosure in banking and other fields. This research encourages researchers and analysts to extend their knowledge on this field by providing them a useful tool to examine credit risk disclosure in the banking industry. The study provides evidence of a relationship between credit risk disclosure and bank characteristics by adopting a generalized linear model. In this regard, large and high-leverage banks are more likely to disclose meaningful risk information in the narrative sections of their annual reports. Highly leveraged companies tend to present more narrative and meaningful information in their annual reports. The enhancements of bank credit risk disclosure are related to the bank size and leverage. Bank age and profitability have no association with the extent of risk disclosure in their annual reports.

Given the limited sample analyzed, the analysis opens the way for a more comprehensive analysis of larger samples and longer time horizons. Future research also can focus on across countries and banks (both Islamic and conventional) comparisons. This study is based entirely on information published in annual reports. However, qualitative data from interviews with different stakeholders and users could be helpful for future studies. Further, equal weight is used for each item in the risk disclosure index, which might not reflect the importance level of users of annual reports. Future research should consider this issue when addressing similar subjects. Finally, in light of the significant challenges to the global economy, particularly the COVID-19 pandemic, researchers are encouraged to examine the impact of pandemic on the bank's financial reporting.

\section{References}

Abdallah, A. A.-N., Hassan, M. K., \& McClelland, P. L. (2015). Islamic financial institutions, corporate governance, and corporate risk disclosure in Gulf Cooperation Council countries. Journal of Multinational Financial Management, 31, 63-82.

Abed, S., Al-Najjar, B., \& Roberts, C. (2016). Measuring annual report narratives disclosure: Empirical evidence from forward-looking information in the UK prior the financial crisis. Managerial Auditing Journal, 31(4-5), 338-361.

Abraham, S., \& Cox, P. (2007). Analysing the determinants of narrative risk information in UK FTSE 100 annual reports. The British Accounting Review, 39(3), 227-248.

Adams, R. B., \& Ferreira, D. (2009). Women in the boardroom and their impact on governance and performance. Journal of financial economics, 94(2), 291-309.

Agarwal, P., \& O'Hara, M. (2007). Information risk and capital structure. Working Paper, Cornell University.

Ahn, T.-S., \& Lee, J. (2004). Determinants of voluntary disclosures in management disclosure and analysis (MD\&A): Korean evidence. Retrieved 25 Desember 2014, from http://ssrn.com/

Akhtaruddin, M., Hossain, M. A., Hossain, M., \& Yao, L. (2009). Corporate governance and voluntary disclosure in corporate annual reports of Malaysian listed firms. Journal of Applied Management Accounting Research, 7(1), 1. 


\section{Macrothink}

International Journal of Accounting and Financial Reporting ISSN 2162-3082

Al-Maghzom, A., Hussainey, K., \& Aly, D. (2016). The level of risk disclosure in listed banks: Evidence from Saudi Arabia. Corporate Ownership and Control, 14(1 (continued 1)), 175-194.

Alfraih, M. M., \& Almutawa, A. M. (2014). Firm-specific characteristics and corporate financial disclosure: Evidence from an emerging market. International Journal of Accounting and Taxation, 2(3), 55-78.

Alsaeed, K. (2006). The association between firm-specific characteristics and disclosure. Managerial Auditing Journal, 21(5), 476-96.

Altman, E. I., \& Saunders, A. (1997). Credit risk measurement: Developments over the last 20 years. Journal of Banking \& Finance, 21(11-12), 1721-1742.

Amran, A., Bin, A. M. R., \& Hassan, B. C. H. M. (2009). Risk reporting. Managerial Auditing Journal, 24(1), 39-57.

Amran, A., \& Devi, S. S. (2008). The impact of government and foreign affiliate influence on corporate social reporting: The case of Malaysia. Managerial Auditing Journal, 23(4), 386-404.

Aryani, D. N., \& Hussainey, K. (2017). The determinants of risk disclosure in the Indonesian non-listed banks. International Journal of Trade and Global Markets, 10(1), 58-66.

Asllanaj, R. (2018). Does Credit Risk Management affect the Financial Performance of Commercial Banks in Kosovo?. International Journal of Finance \& Banking Studies (2147-4486), 7(2), 49-57.

Barakat, A., \& Hussainey, K. (2013). Bank governance, regulation, supervision, and risk reporting: Evidence from operational risk disclosures in European banks. International Review of Financial Analysis, 30, 254-273.

Barth, M. E., \& Landsman, W. R. (2010). How did financial reporting contribute to the financial crisis?. European accounting review, 19(3), 399-423.

Beasley, M. S., Clune, R., \& Hermanson, D. R. (2005). Enterprise risk management: An empirical analysis of factors associated with the extent of implementation. Journal of Accounting and Public Policy, 24(6), 521-531.

Beneish, M. D., Miller, B. P., \& Yohn, T. L. (2015). Macroeconomic evidence on the impact of mandatory IFRS adoption on equity and debt markets. Journal of Accounting and Public Policy, 34(1), 1-27.

Beretta, S., \& Bozzolan, S. (2004). A framework for the analysis of firm risk communication. The International Journal of Accounting, 39(3), 265-288.

Beretta, S., \& Bozzolan, S. (2008). Quality versus quantity: the case of forward-looking disclosure. Journal of Accounting, Auditing \& Finance, 23(3), 333-376. 


\section{Macrothink}

International Journal of Accounting and Financial Reporting ISSN 2162-3082 2021, Vol. 11, No. 3

Berger, A. N., El Ghoul, S., Guedhami, O., \& Roman, R. A. (2017). Internationalization and bank risk. Management Science, 63(7), 2283-2301.

Bessis, J. (2011). Risk management in banking. John Wiley \& Sons.

Bharath, S. T., \& Shumway, T. (2008). Forecasting default with the Merton distance to default model. The Review of Financial Studies, 21(3), 1339-1369.

Blažeková, P. (2017). The impact of IFRS 9 (increase in credit risk provisioning) on banks' regulatory capital. Comenius Management Review, 11(2), 27-42.

Boussanni, A., Desrochers, J., \& Préfontaine, J. (2008). Liquidity risk financial disclosure: the case of large European financial groups. International Business \& Economics Research Journal (IBER), 7(7), 47-56.

Bozzolan, S., Trombetta, M., \& Beretta, S. (2009). Forward-looking disclosures, financial verifiability and analysts' forecasts: A study of cross-listed European firms. European accounting review, 18(3), 435-473.

Brown, K., \& Moles, P. (2014). Credit risk management. Edinburgh Business School, Edinburgh (United Kingdom), Vol. 16.

Cabedo, J. D., \& Tirado, J. M. (2004). The disclosure of risk in financial statements. Accounting Forum, 28(2), 181-200.

Calabrese, R., \& Osmetti, S. A. (2013). Modelling small and medium enterprise loan defaults as rare events: the generalized extreme value regression model. Journal of Applied Statistics, 40(6), 1172-1188.

Chow, C. W., \& Wong-Boren, A. (1987). Voluntary financial disclosure by Mexican corporations. Accounting Review, 533-541.

CMA. (2007). Capital Market Authority. Retrieved from http://www.cma.org.sa

Combes-ThuÚlin, E., Henneron, S., \& Touron, P. (2006). Risk regulations and financial disclosure: An investigation based on corporate communication in French traded companies. Corporate Communications: An International Journal, 11(3), 303-326.

Cooke, T. E. (1989). Disclosure in the corporate annual reports of Swedish companies. Accounting and business research, 19(74), 113-124.

Dahel, R. (1999). Volatility in Arab stock markets. Citeseer, Paper presented at the workshop on 'Arab stock markets: recent trends and performance', organised by the Arab Planning Institute, Kuwait, March 15-16, 1999.

Demir, V., \& Bahadir, O. (2014). An investigation of compliance with International Financial Reporting Standards by listed companies in Turkey. Accounting and Management Information Systems, 13(1), 4-34.

Deumes, R. (2008). Corporate risk reporting: A content analysis of narrative risk disclosures in prospectuses. The Journal of Business Communication (1973), 45(2), 120-157. 


\section{MlMacrothink}

International Journal of Accounting and Financial Reporting ISSN 2162-3082 2021, Vol. 11, No. 3

Deumes, R., \& Knechel, W. R. (2008). Economic incentives for voluntary reporting on internal risk management and control systems. Auditing: A Journal of Practice \& Theory, 27(1), 35-66.

Diamond, D. W., \& Verrecchia, R. E. (1991). Disclosure, liquidity, and the cost of capital. The journal of Finance, 46(4), 1325-1359.

Dionne, G. (2013). Risk management: History, definition, and critique. Risk Management and Insurance Review, 16(2), 147-166.

Dobler, M. (2005). How informative is risk reporting?-A review of disclosure models. Munich Business Research Working Paper, No. 2005-01. https://doi.org/10.2139/ssrn.640522

Dobler, M., Lajili, K., \& Zéghal, D. (2011). Attributes of corporate risk disclosure: An international investigation in the manufacturing sector. Journal of International Accounting Research, 10(2), 1-22.

El-Bannany, M. (2015). Global financial crisis and credit risk disclosure in the UAE banks. Risk governance \& control: financial markets \& institutions, 5(1), 20-26.

Elshandidy, T., Fraser, I., \& Hussainey, K. (2013). Aggregated, voluntary, and mandatory risk disclosure incentives: Evidence from UK FTSE all-share companies. International Review of Financial Analysis, 30, 320-333.

Elshandidy, T., Fraser, I., \& Hussainey, K. (2015). What drives mandatory and voluntary risk reporting variations across Germany, UK and US?. The British Accounting Review, 47(4), 376-394.

Falgi, K. I. (2009). Corporate governance in Saudi Arabia: A stakeholder perspective. University of Dundee, UK.

Faybishenko, B., Hazen, T. C., Long, P. E., Brodie, E. L., Conrad, M. E., Hubbard, S. S., . . . Chakraborty, R. (2008). In situ long-term reductive bioimmobilization of $\mathrm{Cr}$ (VI) in groundwater using hydrogen release compound. Environmental Science \& Technology, $42(22), 8478-8485$.

Frolov, M. (2006). Bank credit risk disclosure in Japan. Journal of Banking Regulation, 7(3-4), 221-242.

Gernon, H., \& Meek, G. (2001). Accounting. An International Perspective. MCGraw-Hill, Singapore.

Ghazali, N. A. M., \& Weetman, P. (2006). Perpetuating traditional influences: Voluntary disclosure in Malaysia following the economic crisis. Journal of International Accounting, Auditing and Taxation, 15(2), 226-248.

Glaum, M., \& Street, D. L. (2003). Compliance with the disclosure requirements of Germany's new market: IAS versus US GAAP. Journal of International Financial Management \& Accounting, 14(1), 64-100. 


\section{Macrothink}

International Journal of Accounting and Financial Reporting ISSN 2162-3082

Grassa, R., Moumen, N., \& Hussainey, K. (2019). What drives risk disclosure in Islamic and conventional banks? An international comparison. International Journal of Finance \& Economics. https://doi.org/10.1002/ijfe.2122

Grassa, R., Moumen, N., \& Hussainey, K. (2020). Is bank creditworthiness associated with risk disclosure behavior? Evidence from Islamic and conventional banks in emerging countries. Pacific-Basin Finance Journal, 61. https://doi.org/10.1016/j.pacfin.2020, 101327

Gray, S. J., Campbell, L. G., \& Shaw, J. C. (1984). International Financial Reporting: A comparative international survey of accounting requirements and practices in 30 countries. London: Macmillan.

Hamid, F. Z. A. (2004). Corporate social disclosure by banks and finance companies: Malaysian evidence. Corporate Ownership and Control, 1(4), 118-130.

Hassan, A. (2009). Risk management practices of Islamic banks of Brunei Darussalam. The Journal of Risk Finance, 10(1), 23-37.

Hassan, M. K. (2009). UAE corporations- ${ }^{-}$specific characteristics and level of risk disclosure. Managerial Auditing Journal, 24(7), 668-687.

IASB, I. A. S. B. (2007). International Financial Reporting Standard 7: Financial Instruments Disclosures from International Accounting Standards Board. London.

Ibrahim, A., Habbash, M., \& Hussainey, K. (2019). Corporate governance and risk disclosure: evidence from Saudi Arabia. International Journal of Accounting, Auditing and Performance Evaluation, 15(1), 89-111.

IMF, I. M. F. (2013). Saudi Arabia: Financial Sector AssessmentnProgram Update-Detailed Assessment of Observance of the IOSCO objectives and principles of securities regulation. Retrieved from https://www.imf.org/external/pubs/ft/scr/2013/cr13213.pdf

Inchausti, B. G. (1997). The influence of company characteristics and accounting regulation on information disclosed by Spanish firms. European accounting review, 6(1), 45-68.

Jensen, M. C., \& Meckling, W. H. (1976). Theory of the firm: Managerial behavior, agency costs and ownership structure. Journal of financial economics, 3(4), 305-360.

Jorgensen, B. N., \& Kirschenheiter, M. T. (2003). Discretionary risk disclosures. The Accounting Review, 78(2), 449-469.

Konishi, N., \& Ali, M. M. (2007). Risk reporting of Japanese companies and its association with corporate characteristics. International Journal of Accounting, Auditing and Performance Evaluation, 4(3), 263-285.

Krippendorff, K. (2018). Content analysis: An introduction to its methodology. Sage publications.

Kristandl, G., \& Bontis, N. (2007). The impact of voluntary disclosure on cost of equity capital estimates in a temporal setting. Journal of intellectual capital, 8(4), 577-594. 


\section{MInstitute ${ }^{\text {Mut }}$}

International Journal of Accounting and Financial Reporting ISSN 2162-3082

Lajili, K. (2009). Corporate risk disclosure and corporate governance. Journal of Risk and Financial Management, 2(1), 94-117.

Linsley \& Shrives. (2006). Risk reporting: A study of risk disclosures in the annual reports of UK companies. The British Accounting Review, 38(4), 387-404.

Linsley, P., \& Kajuter, P. (2008). Restoring reputation and repairing legitimacy: A case study of impression management in response to a major risk event at Allied Irish Banks plc. International Journal of Financial Services Management, 3(1), 65-82.

Linsley, P., \& Shrives, P. (2000). Risk management and reporting risk in the UK. Journal of Risk, 3, 115-129.

Lookman, A. A. (2009). Bank borrowing and corporate risk management. Journal of Financial Intermediation, 18(4), 632-649.

Maffei, M., Aria, M., Fiondella, C., Spanò, R., \& Zagaria, C. (2014). (Un) useful risk disclosure: explanations from the Italian banks. Managerial Auditing Journal, 29(7), 621-648.

Miihkinen, A. (2012). What drives quality of firm risk disclosure?: the impact of a national disclosure standard and reporting incentives under IFRS. The International Journal of Accounting, 47(4), 437-468.

Mohobbot, A. M., \& Konishi, N. (2005). The UK Guidelines for Company Risk ReportingAn Evaluation. Okayama Economic Review, 37(1), 1-18.

Muslu, V., Radhakrishnan, S., Subramanyam, K., \& Lim, D. (2015). Forward-looking MD\&A disclosures and the information environment. Management Science, 61(5), 931-948.

Nahar, S., Azim, M., \& Jubb, C. (2016). The determinants of risk disclosure by banking institutions. Asian Review of Accounting, 24(4), 426-444.

Naser, K., Al-Khatib, K., \& Karbhari, Y. (2002). Empirical evidence on the depth of corporate information disclosure in developing countries: The case of Jordan. International journal of commerce and management, 12(3-4), 122-156.

Nier, E., \& Baumann, U. (2006). Market discipline, disclosure and moral hazard in banking. Journal of Financial Intermediation, 15(3), 332-361.

Ntim, C. G., Lindop, S., \& Thomas, D. A. (2013). Corporate governance and risk reporting in South Africa: A study of corporate risk disclosures in the pre-and post-2007/2008 global financial crisis periods. International Review of Financial Analysis, 30, 363-383.

Ogunwole, P. B. (2019). Determinants of Market Discipline and Risk Disclosure Practices of Listed Deposit Money Banks in Nigeria. (PhD thesis). Kwara State University (Nigeria).

Oliveira, J., Rodrigues, L. L., \& Craig, R. (2011a). Risk-related disclosure practices in the annual reports of Portuguese credit institutions: an exploratory study. Journal of Banking Regulation, 12(2), 100-118. 


\section{MInstitute Macrothink $_{\text {Int }}$}

International Journal of Accounting and Financial Reporting ISSN 2162-3082

Oliveira, J., Rodrigues, L. L., \& Craig, R. (2011b). Risk-related disclosures by non - finance companies. Managerial Auditing Journal, 26(9), 817-839.

Onour, I. A. (2004). Testing weak-form efficiency of Saudi stock exchange market. SSRN 611209.

Papke, L. E., \& Wooldridge, J. M. (1996). Econometric methods for fractional response variables with an application to 401 (k) plan participation rates. Journal of Applied Econometrics, 11(6), 619-632.

Patelli, L., \& Prencipe, A. (2007). The relationship between voluntary disclosure and independent directors in the presence of a dominant shareholder. European Accounting Review, 16(1), 5-33.

Pepe, M. S. (2000). An interpretation for the ROC curve and inference using GLM procedures. Biometrics, 56(2), 352-359.

Piesse, J., Strange, R., \& Toonsi, F. (2012). Is there a distinctive MENA model of corporate governance?. Journal of Management \& Governance, 16(4), 645-681.

Popova, T., Georgakopoulos, G., Sotiropoulos, I., \& Vasileiou, K. Z. (2013). Mandatory disclosure and its impact on the company value. International Business Research, 6(5), 1-16.

Rajab, B., \& Schachler, M. (2009). Corporate risk disclosure by UK firms: trends and determinants. World Review of Entrepreneurship, Management and Sustainable Development, 5(3), 224-243.

Romero, S., Jeffers, A. E., \& DeGaetano, L. A. (2014). An overview of sustainability reporting practices. The CPA Journal, 84(3), 68-71.

Sakani. (2020, July). Media center. Retrieved from https://www.housing.gov.sa/en/node/1638 SAMA, S. C. $\quad$ B. $\quad$ F. (2021). Retrieved from https://www.sama.gov.sa/en-us/about/pages/samafunction.aspx

Sánchez-Ballesta, J. P., \& Lloréns, M. B. (2010). Monitoring, reputation and accountability in issuing banks in mid-nineteenth-century Spain. Explorations in Economic History, 47(4), 403-419.

Saudi Exchange. (2009). Saudi Stock Exchange Law. Retrieved from https://www.saudiexchange.sa/wps/portal

Scannella, E. (2018). Market risk disclosure in banks' balance sheets and the pillar 3 report: the case of Italian banks. In Contemporary issues in banking (pp. 53-90). Springer.

Scannella, E., \& Polizzi, S. (2018). Market risk disclosure in banking: an empirical analysis on four global systemically important European banks. Journal of Banking Regulation, 19(2), 87-100. 


\section{Mll Macrothink}

International Journal of Accounting and Financial Reporting

ISSN 2162-3082 2021, Vol. 11, No. 3

Scannella, E., \& Polizzi, S. (2020). How to measure bank credit risk disclosure? Testing a new methodological approach based on the content analysis framework. Journal of Banking Regulation, 1-23.

Scannella, E., \& Polizzi, S. (2021). How to measure bank credit risk disclosure? Testing a new methodological approach based on the content analysis framework. Journal of Banking Regulation, 22(1), 73-95.

Shrives, P., \& Linsley, P. (2003). Risk disclosure in UK and German annual reports: a comparative study. Paper presented at the European Accounting Association 26th Annual Conference. Seville, April.

Sidawi, B. (2014). An evaluation of the performance of the housing finance system in the Kingdom of Saudi Arabia. International Journal of Housing Markets and Analysis, 7(2), 156-174.

Solomon, J. F., Solomon, A., Norton, S. D., \& Joseph, N. L. (2000). A conceptual framework for corporate risk disclosure emerging from the agenda for corporate governance reform. The British Accounting Review, 32(4), 447-478.

Taylor, D. (2011). Corporate risk disclosures: the influence of institutional shareholders and the audit committee. Journal of Corporate Finance, 9(1), 1-27.

Tonkin, D. J. (1989). World survey of published accounts: An analysis of 200 annual reports from the world's leading companies. Lafferty Publications.

Woods, M., Dowd, K., \& Humphrey, C. (2008). The value of risk reporting: a critical analysis of value-at-risk disclosures in the banking sector. International Journal of Financial Services Management, 3(1), 45-64.

Zhu, X., Yang, S. Y., \& Moazeni, S. (2016). Firm risk identification through topic analysis of textual financial disclosures. 2016 IEEE Symposium Series on Computational Intelligence (SSCI), 1-8. 


\section{Macrothink \\ International Journal of Accounting and Financial Reporting \\ ISSN 2162-3082 \\ 2021, Vol. 11, No. 3}

\section{Appendix A. Credit Risk Disclosure Index}

Table of scoring model: the analytical grid of credit risk disclosure indicators (score 0,1 )

Section A-Information on credit risk exposures

Potential credit risk exposures (on-balance sheet)

Credit Risk Exposure by domestic vs. foreign exposures.

By current vs. past periods of impairment Total credit exposures

Section B-Bank loan portfolio disclosure

Expected average funding cost in the next period

Total loans and bills (impaired + non-impaired)

By home region vs. other regions

By small vs. other business borrowers

By housing loans vs. others

Loans and bills with fixed interest rate by remaining term to maturity

Loans by the use of borrowed funds by industry (sector)

Section $\mathbf{C}-$ Key aspects of credit risk management in banking

Measuring credit losses

Qualitative disclosure on non-performing loans portfolio

By before vs. after partial write-offs

Section D-Credit risk exposure limits and tolerance

Capital structure and adequacy - tier $1 \& 2$ capital and ratios

Changes in capital structure

Capital management strategy

Section E-Credit risk mitigation/transfer instruments

\begin{tabular}{l}
\hline Information on collateral \\
Information on credit derivatives \\
\hline Hedging \\
\hline Collateral Assets \\
\hline Section F-Internal Credit risk management disclosure \\
\hline Internal audit function \\
\hline Explanation of credit risk control systems \\
\hline Business Disruption and Systems Failures \\
\hline Future changes to accounting policies \\
\hline Statutory penalties and sanctions \\
\hline Section G-Other key elements of bank credit risk \\
\hline Credit rating \\
\hline legal risks
\end{tabular}

\section{Copyright Disclaimer}

Copyright for this article is retained by the author(s), with first publication rights granted to the journal.

This is an open-access article distributed under the terms and conditions of the Creative Commons Attribution license (http://creativecommons.org/licenses/by/4.0/) 